(c) American Dairy Science Association, 2004.

\title{
Short Communication: Influence of Staphylococcus aureus Intramammary Infection on Serum Copper, Zinc, and Iron Concentrations
}

\author{
J. R. Middleton, ${ }^{1}$ C. D. Luby, ${ }^{1}$ L. Viera, ${ }^{1}$ J. W. Tyler, ${ }^{1}$ and S. Casteel ${ }^{2}$ \\ ${ }^{1}$ Department of Veterinary Medicine and Surgery, \\ University of Missouri, Columbia 65211 \\ ${ }^{2}$ Veterinary Medicine Diagnostic Laboratory, \\ University of Missouri, Columbia 65211
}

\section{ABSTRACT}

The goal of the present study was to characterize changes in serum trace mineral concentrations in cattle with experimentally induced Staphylococcus aureus mastitis. Nine primiparous Holstein-Friesian cattle were challenged with approximately $150 \mathrm{cfu}$ of Staph. aureus ATCC29740 by intramammary infusion on d 6, 7 , and 8 of lactation. Serum $\mathrm{Cu}, \mathrm{Zn}$, and Fe concentrations were determined immediately before and at 24 , 48 , and $72 \mathrm{~h}$ after the final intramammary infusion of Staph. aureus. Infection status (cfu/mL of Staph. aureus), milk somatic cell count, and mastitis score were also determined at these times. Infection resulted in a decrease in mean serum $\mathrm{Cu}, \mathrm{Zn}$, and Fe concentrations to 89,83 , and $81 \%$ of preinfection concentrations at $24 \mathrm{~h}$ postchallenge. One-way analysis of variance for repeated measures demonstrated a significant change in serum zinc concentration. The reductions in trace mineral concentrations were of less magnitude than observed following experimental $E$. coli mastitis.

(Key words: Staphylococcus aureus, mastitis, copper, zinc, iron)

Alterations in plasma $\mathrm{Cu}, \mathrm{Zn}$, and $\mathrm{Fe}$ concentrations have been documented in experimental coliform mastitis models (Erskine and Bartlett, 1993; Lohuis et al., 1988a, 1988b, 1990). Lohuis and co-workers (1988b) demonstrated a dramatic decline in plasma $\mathrm{Zn}$ and $\mathrm{Fe}$ concentrations following intramammary infusion of 2 $\times 10^{6} \mathrm{cfu}$ of Escherichia coli. Similarly, Erskine and Bartlett (1993) showed that intramammary infusion of a minimum infective dose (50 cfu) of $E$. coli resulted in a decline in mean serum concentrations of $\mathrm{Zn}, \mathrm{Fe}$, and $\mathrm{Cu}$ to 28,35 , and $52 \%$ of prechallenge concentrations,

Received: July 9, 2003.

Accepted: November 3, 2003.

Corresponding Author: J. R. Middleton; e-mail: middletonjr@ missouri.edu. respectively. The decline in mean serum $\mathrm{Cu}$ concentration was not significant $(P>0.05)$.

Reductions in serum $\mathrm{Zn}$ and $\mathrm{Fe}$ are regarded as nonspecific host defense mechanisms against bacterial infection. Lohuis and co-workers (1990) demonstrated that the numbers of $E$. coli shed from inoculated mammary quarters were positively correlated with plasma $\mathrm{Zn}$ and Fe concentrations. Iron withholding during microbial infection is regarded as host protective and is mediated by a number of host mechanisms, including decreased intestinal absorption of $\mathrm{Fe}$, decreased release of Fe from macrophages, increased Fe storage through increased synthesis of ferritin, release of lactoferrin (an iron-binding glycoprotein) from neutrophils and epithelial cells, and, in some species, increased urinary $\mathrm{Fe}$ excretion (Weinberg, 1984). Microbial metabolism requires trace concentrations of $\mathrm{Zn}$ (Sugarman, 1983). In hamsters, a decrease in serum $\mathrm{Zn}$ concentrations following intraperitoneal administration of endotoxin has been attributed to increased uptake by the liver (Etzel et al., 1982). In addition, increases in metallothionein (a Zn-binding protein) have been documented during acute bacterial infection (Sobocinski et al., 1978). However, the complete role of $\mathrm{Zn}$ and its interaction with $\mathrm{Fe}$ as a nonspecific host defense against bacterial infection remain to be understood fully. Alterations in serum $\mathrm{Cu}$ concentrations have been recorded in several species using endotoxin or gram-negative bacterial challenge models (Etzel et al., 1982; Barber et al., 1988; Erskine and Bartlett, 1993). In rats and hamsters, a rise in serum $\mathrm{Cu}$ concentration was observed following parenteral administration of endotoxin. The increase in serum $\mathrm{Cu}$ concentration was attributed to increased synthesis of ceruloplasmin by the liver. In contrast to the rodent experiments, Erskine and Bartlett (1993) documented a decrease in plasma $\mathrm{Cu}$ concentrations following experimental IMI with $E$. coli. They attributed this difference to the fact that their experimental subjects were marginally $\mathrm{Cu}$ deficient at the beginning of their study. Previous work in rats had shown that $\mathrm{Cu}$-deficient rats did not exhibit increased serum ceru- 
loplasmin concentrations following injection of interleukin-1, an inflammatory mediator thought to increase ceruloplasmin synthesis following endotoxin release (Barber et al., 1988).

Staphylococcus aureus is a contagious mastitis pathogen of dairy cattle that generally causes chronic, subclinical mastitis. The inflammatory response following Staph. aureus IMI is expected to be minimal in contrast to the profound inflammatory response described for acute coliform mastitis. Hence, the alterations in serum $\mathrm{Cu}, \mathrm{Zn}$, and $\mathrm{Fe}$ associated with acute coliform mastitis are not likely to occur in an experimental subclinical Staph. aureus mastitis model. No data could be found regarding alterations in serum $\mathrm{Cu}, \mathrm{Zn}$, and $\mathrm{Fe}$ concentrations following experimental Staph. aureus IMI. The objective of the present study was to quantify serum $\mathrm{Cu}, \mathrm{Zn}$, and $\mathrm{Fe}$ concentrations before and after experimental Staph. aureus IMI. The hypothesis was that Staph. aureus IMI would not cause significant alterations in serum $\mathrm{Cu}, \mathrm{Zn}$, and $\mathrm{Fe}$ concentrations.

The study population consisted of 12 healthy primiparous Holstein-Friesian dairy cattle. Cattle were fed a TMR balanced for stage of lactation and had free-choice access to water. Cattle were milked twice daily in a double-three parabone parlor and housed in a free-stall facility on sand bedding. The experimental protocol was approved by the University of Missouri institutional animal care and use committee.

Prechallenge IMI status was determined by culturing mammary quarter foremilk samples aseptically collected on d 1 to 5 of lactation. All cattle free of Staph. aureus IMI and free of other major mastitis pathogens $(\mathrm{n}=9)$ were included in the trial. Cattle were infused with Staph. aureus (ATCC 29740, American Type Culture Collection, Rockville, MD) in a single infection-free mammary quarter on d 6, 7, and 8 of lactation. We chose to challenge with Staph. aureus on 3 consecutive days in order to ensure all heifers developed an IMI. Previous experience with experimentally infecting cattle with Staph. aureus suggested that this would give the best chance of getting all cattle infected (Middleton, unpublished data). Geometric mean colony-forming units of Staph. aureus infused on d 6, 7, and 8 of lactation were 154, 164, and 193, respectively. There were no significant differences in inoculum size between cows or day of infusion ( $P=0.34$ and $P=0.41$, respectively).

Mammary quarter foremilk samples were aseptically collected immediately prior to experimental challenge (time 0 ) and at 24, 48, and $96 \mathrm{~h}$ postchallenge from all lactating quarters for milk culture and SCC determinations. Time 0 corresponds to d 6 of lactation and 24, 48 , and $96 \mathrm{~h}$ postchallenge correspond to $\mathrm{d} 9,10$, and 12 of lactation, respectively. All milk samples for bacterial cultivation were stored at $-20^{\circ} \mathrm{C}$ until further analysis.
Minimum storage time prior to culture was $24 \mathrm{~h}$. All milk samples for SCC determination were mixed with a proprietary preservative (Mid-South Dairy Records, Springfield, MO) and stored at $6^{\circ} \mathrm{C}$. Somatic cell count samples were shipped to an external laboratory (MidSouth Dairy Records, Springfield, MO) every few days for analysis. Mammary glands and milk secretions were scored once daily on d 1 to 12 of lactation for evidence of mastitis. Scoring criteria were: $0=$ no overt changes in gland or milk, 1 = overt changes in milk with no observed mammary gland inflammation, 2 = local inflammation of the mammary gland accompanied by overt changes in milk, and $3=$ severe clinical mastitis with systemic symptoms. Whole blood $(10 \mathrm{~mL})$ samples were collected into evacuated glass tubes with inert rubber stoppers (Royal Blue Top Vacutainer Tubes, Becton Dickinson, Franklin Lakes, NJ) via coccygeal venipunture immediately prior to challenge (time 0 ) and at 24,48 , and $96 \mathrm{~h}$ postchallenge to determine serum $\mathrm{Cu}$, $\mathrm{Zn}$, and Fe concentrations. Blood was allowed to clot, and serum was harvested by centrifugation $(1000 \times g$, $15 \mathrm{~min}$ ) and stored at $-80^{\circ} \mathrm{C}$ until analyzed.

All milk samples for bacterial cultivation were thawed at room temperature and cultured according to established guidelines (Hogan et al., 1999). Briefly, approximately $0.03 \mathrm{~mL}$ of milk was spread evenly across half a Columbia blood agar plate with 5\% sheep blood (Remel, Lenexa, KS) using a sterile, cotton-tipped applicator. Plates were incubated at $37^{\circ} \mathrm{C}$ for $24 \mathrm{~h}$ and at room temperature for a further $24 \mathrm{~h}$. Plates were read at 24 and $48 \mathrm{~h}$. Bacterial isolates were initially identified based on colonial morphology, hemolytic patterns, $\mathrm{KOH}$ gelation, and catalase reaction (Hogan et al., 1999). All suspect staphylococci were subjected to a coagulase test (Hogan et al., 1999). All coagulasepositive isolates were speciated using a commercial biochemical typing system (api STAPH, bioMerieux, Hazelwood, MO). Staphylococcus aureus bacteria counts (cfu/mL) were determined for the challenged mammary quarter immediately prior to infusion (time 0 ) and at 24,48 , and $96 \mathrm{~h}$ postchallenge by counting the number of colonies on the blood agar plate and dividing by 0.03 . If the number of colonies were too numerous to count, serial 10-fold dilutions of milk were made in PBS solution (Dulbecco's PBS, Gibco, Grand Island, NY) and the appropriate calculations made to arrive at $\mathrm{cfu} / \mathrm{mL}$ of Staph. aureus. All suspect streptococci were further differentiated using CAMP/aesculin media (Remel, Lenexa, KS). Suspected gram-negative (KOH gelation positive) isolates were not further differentiated.

Milk SCC determinations were performed by the regional Dairy Herd Improvement Association laboratory (Mid-South Dairy Records) using an electronic counter. Serum $\mathrm{Cu}, \mathrm{Zn}$, and $\mathrm{Fe}$ concentrations were determined 


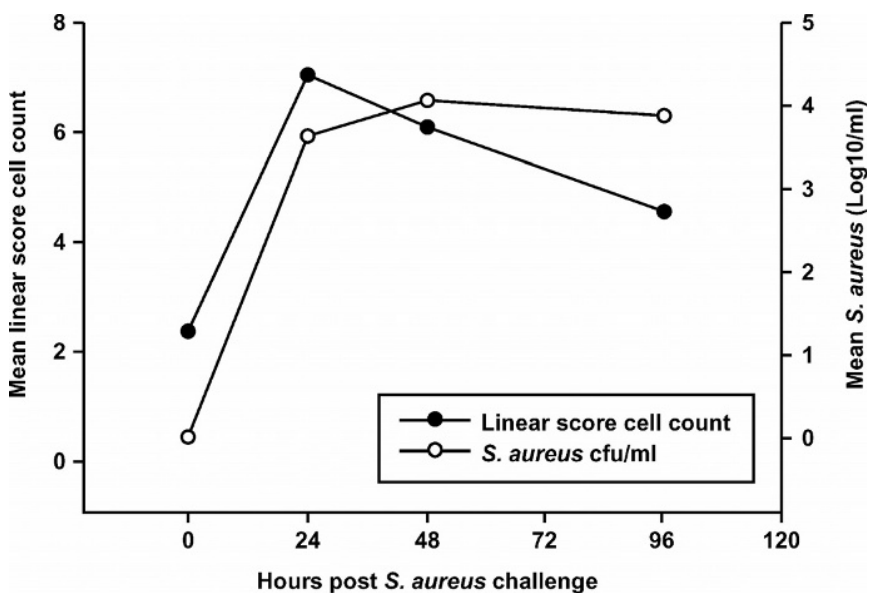

Figure 1. Mean linear score SCS and mean $\log 10 \mathrm{cfu} / \mathrm{mL}$ of Staphylococcus aureus in the challenged mammary quarter over time. Time 0 represents mean prechallenge linear score cell count.

at the Veterinary Medical Diagnostic Laboratory (University of Missouri, Columbia) by atomic absorption spectrophotometry according to established guidelines (Osheim, 1983; Osheim and Ross, 1985).

Means and standard deviations were calculated for serum $\mathrm{Cu}, \mathrm{Zn}$, and $\mathrm{Fe}$ concentrations immediately prechallenge (time 0 ) and at 24,48 , and $96 \mathrm{~h}$ postchallenge. Similarly, means and standard deviations were calculated for SCC (as linear scores) and Staph. aureus bacterial counts (as $\log 10 \mathrm{cfu} / \mathrm{mL}$ ). Data were analyzed using a one-way analysis of variance (ANOVA) for repeated measures (NCSS 97, Number Cruncher Statistical Software, Kaysville, UT). Dependent variables were serum $\mathrm{Cu}, \mathrm{Zn}$, and Fe concentrations (ppm), linear score SCC, and Staph. aureus count $(\log 10 \mathrm{cfu} / \mathrm{mL})$. Independent variables were cow (random variable), time (fixed variable), and error. Results were considered significant at $P<0.05$. When significant differences were detected with one-way ANOVA for repeated measures, Duncan's multiple-comparison test was used to determine which time periods differed from each other (NCSS 97, Number Cruncher Statistical Software, Kaysville, UT).

All challenged mammary quarters became infected with Staph. aureus and maintained their infections throughout the follow-up period. Three of the nine enrolled cattle developed clinical Staph. aureus mastitis (mastitis score 2) in the challenged mammary quarter, which persisted until $96 \mathrm{~h}$ postchallenge. All other cattle had subclinical Staph. aureus mastitis in the challenged mammary quarter. The median mastitis score for all challenged mammary quarters was 0 . Mean linear score SCC and Staph. aureus bacterial counts (log10 $\mathrm{cfu} / \mathrm{mL}$ ) in the challenged mammary quarter over time are shown in Figure 1. Linear scores in the Staph.

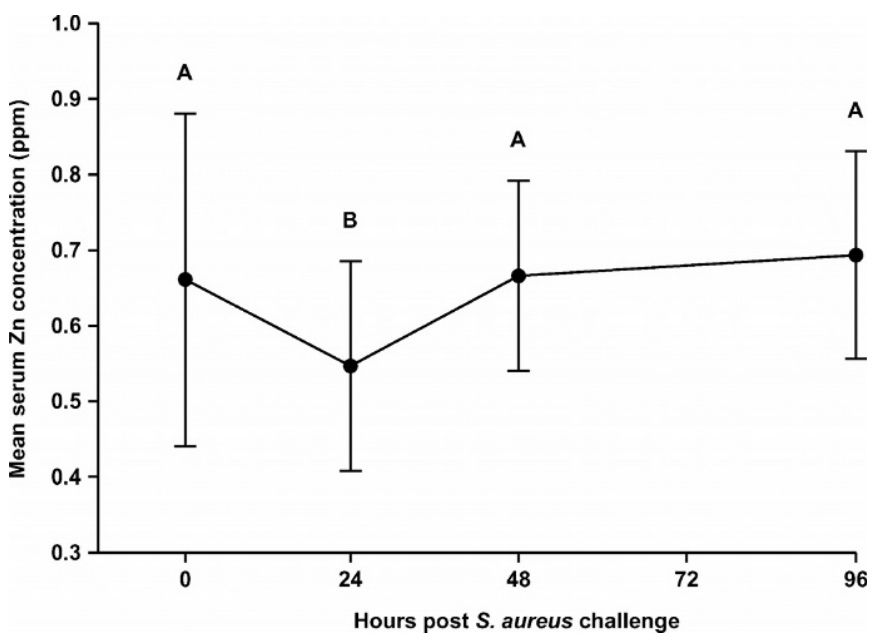

Figure 2. Mean serum $\mathrm{Zn}$ concentration over time. Time points with different letters were significantly different from each other $(P=0.02)$. Error bars represent \pm one standard deviation. Time 0 represents mean prechallenge serum $\mathrm{Zn}$ concentration.

aureus-infected quarter were significantly greater than prechallenge levels at 24 and $48 \mathrm{~h}$ postchallenge $(P=$ $0.0002)$. Linear scores were not significantly different from prechallenge levels in any of the unchallenged mammary quarters at 24,48 , and $96 \mathrm{~h}$ postchallenge ( $P$ $>0.06$ ). Staphylococcus aureus bacterial concentrations $(\log 10 \mathrm{cfu} / \mathrm{mL})$ in the challenged mammary quarter were significantly $(P<0.01)$ elevated following challenge but did not differ at 24,48 , and $96 \mathrm{~h}$ postchallenge, and there was no significant difference in the number of Staph. aureus $(\log 10 \mathrm{cfu} / \mathrm{mL})$ shed from the infected quarter between cows postchallenge $(P=0.62)$.

Means and standard deviations for serum $\mathrm{Cu}$ concentrations at time 0 (prechallenge) and 24,48 , and $96 \mathrm{~h}$ postchallenge were $0.89 \pm 0.15,0.84 \pm 0.11,0.88 \pm 0.10$, and $0.89 \pm 0.16 \mathrm{ppm}$, respectively. There were no significant differences in serum $\mathrm{Cu}$ concentrations over time $(P=0.39)$. In contrast to the relatively constant serum $\mathrm{Cu}$ concentrations, serum $\mathrm{Fe}$ and $\mathrm{Zn}$ concentrations declined immediately postchallenge and rebounded by $96 \mathrm{~h}$ postchallenge. Means and standard deviations for serum $\mathrm{Fe}$ concentrations at time 0 and 24,48 , and $96 \mathrm{~h}$ postchallenge were $1.70 \pm 0.67,1.30 \pm$ $0.65,1.23 \pm 0.38$, and $1.66 \pm 0.98 \mathrm{ppm}$, respectively. The decline in serum Fe concentration was not significant $(P=0.22)$. Means and standard deviations for serum $\mathrm{Zn}$ concentrations at each time point are shown graphically in Figure 2. The decline in serum Zn concentration was significant at $24 \mathrm{~h}$ postchallenge $(P=0.02)$.

To our knowledge, alterations in serum $\mathrm{Cu}, \mathrm{Zn}$, and Fe have not been previously characterized for Staph. aureus mastitis. The alterations in serum $\mathrm{Cu}, \mathrm{Zn}$, and Fe concentrations in the Staph. aureus mastitis model 
described here are similar to those described previously in experimental coliform mastitis models in that we observed a decline in serum $\mathrm{Cu}, \mathrm{Zn}$, and Fe concentrations $24 \mathrm{~h}$ after the final Staph. aureus infusion. However, only the decrease in serum $\mathrm{Zn}$ concentration at $24 \mathrm{~h}$ postchallenge was significant $(P=0.02)$. The declines in trace mineral concentrations coincided with a rise in linear score SCC, suggesting that the declines were associated with mammary gland inflammation. Similarly, the rise in linear score SCC was associated with the rise in Staph. aureus $\mathrm{cfu} / \mathrm{mL}$ shed in milk, suggesting that the mammary inflammation was caused by the Staph. aureus IMI.

Decreases in serum trace mineral concentrations in response to bacterial infection are thought to act as a nonspecific host defense mechanism sequestering microminerals such as Fe and $\mathrm{Zn}$, which are vital for normal bacterial growth (Lohuis et al., 1988a). The exact physiology of these trace mineral alterations is not clearly understood, but it is believed that these trace mineral fluxes are related to increased concentrations of acute phase proteins, metal ion chelators, and alterations in host metabolism. Previously, Erskine and Bartlett (1993) showed a decrease in serum $\mathrm{Cu}, \mathrm{Zn}$, and Fe concentrations to 52,28 , and $35 \%$ of prechallenge concentrations at approximately $24 \mathrm{~h}$ post- $E$. coli-challenge in a coliform mastitis model, whereas in the Staph. aureus mastitis model described here, mean serum $\mathrm{Cu}, \mathrm{Zn}$, and Fe concentrations only declined to 89, 83 , and $81 \%$ of prechallenge concentrations at $24 \mathrm{~h}$ postchallenge, respectively.

We can only hypothesize as to why the fluctuations in serum trace-mineral concentrations in our Staph. aureus mastitis model were different from those previously described for $E$. coli mastitis, because no prior studies have evaluated serum trace-mineral fluctuations associated with Staph. aureus mastitis, and we did not correlate the alterations in $\mathrm{Cu}, \mathrm{Zn}$, and $\mathrm{Fe}$ with other indicators of inflammation. Several possibilities exist for the less significant alterations in serum $\mathrm{Cu}$, $\mathrm{Zn}$, and Fe concentrations in our Staph. aureus mastitis model versus those previously reported in $E$. coli mastitis models: (1) the inflammatory response following Staph. aureus intramammary infection is localized to the mammary tissue and released inflammatory mediators have little systemic influence and, therefore, little effect on serum trace mineral concentrations, (2) the more pronounced declines in serum $\mathrm{Cu}, \mathrm{Zn}$, and $\mathrm{Fe}$ concentrations reported in coliform mastitis models occur as a function of endotoxin release that stimulates the release of circulating endogenous mediators that cause the trace-mineral alterations, and/or (3) serum
$\mathrm{Cu}$ and $\mathrm{Fe}$ are less sensitive indicators of inflammation than serum $\mathrm{Zn}$ and, therefore, the milder inflammatory changes noted in Staph. aureus mastitis only influence changes in serum $\mathrm{Zn}$.

In conclusion, the role of serum trace mineral sequestration as a nonspecific host defense against Staph. aureus mastitis is probably of less importance than that described for gram-negative infection. Further research correlating trace-mineral changes in both milk and serum with inflammation-induced factors, such as lactoferrin, metallothionein, and ceruloplasmin, would help better characterize the role of $\mathrm{Cu}, \mathrm{Zn}$, and Fe in Staph. aureus mastitis.

\section{ACKNOWLEDGMENTS}

This research was funded by a USDA Animal Formula Fund Grant (Grant \#CD000142). The authors thank Julie Holle, Ryan Bader, and Marion Butcher for their invaluable assistance with this research.

\section{REFERENCES}

Barber, E. F., and R. J. Cousins. 1988. Interleukin-1 stimulated induction of ceruloplasmin synthesis in normal and copper deficient rats. J. Nutr. 118:375-381.

Erskine, R. J., and P. C. Bartlett. 1993. Serum concentrations of copper, iron, and zinc during Escherichia coli-induced mastitis. J. Dairy Sci. 76:408-413.

Etzel, K. R., M. R. Swerdel, J. N. Swerdel, and R. J. Cousins. 1982. Endotoxin-induced changes in copper and zinc metabolism in the Syrian hamster. J. Nutr. 112:2363-2373.

Hogan, J. S., R. N. Gonzalez, R. J. Harmon, S. C. Nickerson, S. P. Oliver, J. W. Pankey, and K. L. Smith, eds. 1999. Pages 205, 207, 209, 211, 212 in Laboratory Handbook on Bovine Mastitis. rev. ed. Natl. Mastitis Counc. Inc., Madison, WI.

Lohuis, J. A. C. M., W. Van Leeuwen, J. H. M. Verheijden, J. A. H. Smit, A. Brand, and A. S. J. P. A. M. Van Miert. 1988a. Growth of Escherichia coli in whole and skim milk from endotoxin-induced mastitic quarters: In vitro effects of deferoxamine, zinc and iron supplementation. J. Dairy Sci. 71:2772-2781.

Lohuis, J. A. C. M., W. Van Leeuwen, J. H. M. Verheijden, A. S. J. P. A. M. Van Miert, and A. Brand. 1988b. Effect of dexamethasone on experimental Escherichia coli mastitis in the cow. J. Dairy Sci. 71:2782-2789.

Lohuis, J. A. C. M., Y. H. Schukken, J. H. M. Verheijden, A. Brand, and A. S. J. P. A. M. Van Miert. 1990. Effect of severity of systemic signs during the acute phase of experimentally induced Escherichia coli mastitis on milk production losses. J. Dairy Sci. 73:333-341.

Osheim, D. L. 1983. Atomic absorption determination of serum copper: Collaborative study. J. AOAC. 66:1140-1142.

Osheim, D. L., and P. F. Ross. 1985. Atomic absorption spectrophotometric determination of liver copper. J. AOAC 68:44-45.

Sugarman, B. 1983. Zinc and infection. Rev. Infect. Dis. 5:137-147.

Sobocinski, P. Z., W. J. Canterbury, Jr., C. A. Mapes, and R. E. Dinterman. 1978. Involvement of hepatic metallothioneins in hypozincemia associated with bacterial infection. Am. J. Physiol. 234:399-406.

Weinberg, E. D. 1984. Iron withholding: A defense against infection and neoplasia. Physiol. Rev. 64:65-102. 